\title{
THE EXPERIMENTAL STUDY OF THE EFFECT OF RALEUKIN ON DEVELOPMENT OF DITHIZONE DIABETES IN RABBITS
}

\author{
I.P.Bukhtiyarova, S.M.Drogovoz*, Eu.M.Kovalenko \\ Donetsk National Medical University named after M.Gorky \\ National University of Pharmacy*
}

Key words: dithizone diabetes; products of non-enzymatic glycosylation; hypoglycemic action; raleukin

\begin{abstract}
In the structure of endocrine diseases diabetes mellitus (DM) occupies the second place after the thyroid gland pathology. In 2012 there were more than one million people with diabetes in Ukraine, that is why optimization of therapy for this disease is one of the most pressing health and social problems of our time. The pathogenesis basis of the most serious complications of diabetes (thrombosis, atherosclerosis, kidney failure, cataract, etc.) is nonenzymatic glycosylation processes. Taking into account the presence of antioxidant properties [14] in recombinant receptor antagonist IL-1 raleukin and the hypoglycemic action proven in previous studies it was of interest to study its effect on the initial reactions of nonenzymatic glycosylation. This article presents the results of studying the effect of recombinant receptor antagonist IL-1 raleukin obtained in the State Research Institute of High-Purity Biopharmaceuticals of St. Petersburg on the model of dithizonic diabetes in rabbits. It has been found that on the model of dithizonic diabetes in rabbits recombinant receptor antagonist $I L-1$ raleukin has a strong hypoglycemic effect, which intensity is not inferior to anakinra and exceeds metformin. The results of these studies indicate the prospects of further study of the anti-diabetic properties of raleukin in order to include this drug in the treatment of type I diabetes.
\end{abstract}

In the structure of endocrine

diseases diabetes mellitus (DM) occupies the second place after the thyroid gland pathology. In 2012 there were more than one million people with diabetes, $10-15 \%$ of them were with type I diabetes in Ukraine $[3,7]$. Thus, currently one in ten people in the world suffers from explicit or implicit form of diabetes. That is why optimization of therapy for this disease is one of the most pressing health and social problems of our time.

Today we know a lot of reasons that can cause diabetes, such as heredity, genetic or metabolic disorders, viral infections, obesity, poor diet, lack of exercise, stress, poisoning, environmental pollution, complications as a result of taking certain medicines, etc. [1]. In some cases type I diabetes is an autoimmune disease, which is based on a defect of the immune system [8].

The pathogenesis basis of the most serious complications of diabetes (thrombosis, atherosclerosis, kidney failure, cataract, etc.) is nonenzymatic glycosylation processes. Formation of products of early and enhanced glycosylation begins with formation of a covalent bond between the aldehyde group of glucose molecules and the amino reactive protein, which is often localized at the N-terminus of the lysine moiety. The aldimino-bound Schiff base is a volatile compound that within a few hours is subjected to slow chemical transformation into a more stable Amadori product (fructose-lysine), which HbA1c and fructos-

\footnotetext{
I.P.Bukhtiyarova - Candidate of Pharmacy, associate professor of the Department of Management and Economy of Pharmacy of the Donetsk National Medical University named after M.Gorky
}

S.M.Drogovoz - Doctor of Medicine, professor of the Pharmacology Department of the National University of Pharmacy (Kharkiv) amine belong to $[2,12]$. Nonenzymatic binding of glucose to proteins initially leads to reversible and then irreversible metabolic disorders [4].

Taking into account the presence of antioxidant properties [14] in recombinant receptor antagonist IL-1 raleukin and the hypoglycemic action determined in previous studies it was of interest to study its effect on the initial reactions of nonenzymatic glycosylation leading to the formation of products Amadori - HbA1c and fructosamine [11].

The aim of this work is the experimental study of hypoglycemic properties of receptor antagonist IL-1 raleukin obtained in the State Research Institute of High-Purity Biopharmaceuticals of St. Petersburg on the model of dithizonic diabetes in rabbits.

\section{Materials and Methods}

The experimental model of diabetes induced by dithizone - a compound with chelating properties 
Table 1

\section{Dynamics of basal glycemia in rabbits with dithizonic diabetes under the influence of raleukin introduction during 30 days $(n=5)$}

\begin{tabular}{|c|c|c|c|c|c|}
\hline \multirow{2}{*}{ Group of animals } & \multirow{2}{*}{$\begin{array}{l}\text { Initial level, } \\
\mathrm{mmol} / \mathrm{l}\end{array}$} & \multicolumn{3}{|c|}{$\begin{array}{l}\text { Dynamics of basal glycemia after injection in ... days } \\
\qquad(\mathrm{mmol} / \mathrm{l})\end{array}$} & \multirow{2}{*}{$\begin{array}{l}\text { AGC, mmol/l/day } \\
\text { (the 30-th day) }\end{array}$} \\
\hline & & 10 & 20 & 30 & \\
\hline Intact control & $3.54 \pm 0.26$ & $3.69 \pm 0.34$ & $4.12 \pm 0.37$ & $4.09 \pm 0.43$ & $114.5 \pm 13.2$ \\
\hline Control pathology & $16.23 \pm 0.88$ & $15.41 \pm 0.63^{*}$ & $17.58 \pm 0.79^{*}$ & $18.67 \pm 0.94^{*}$ & $523.1 \pm 44.8^{*}$ \\
\hline Raleukin, $7 \mathrm{mg} / \mathrm{kg}$ & $16.08 \pm 0.74$ & $13.07 \pm 0.45 * / * * \&$ & $11.27 \pm 0.49^{*} / * * \# \&$ & $9.34 \pm 0.51 * / * * \# \&$ & $394.8 \pm 28.7^{*} / * *$ \\
\hline Metformin, $30 \mathrm{mg} / \mathrm{kg}$ & $17.27 \pm 1.12$ & $15.13 \pm 0.81^{*}$ & $13.44 \pm 0.42 * / * * \&$ & $11.52 \pm 0.67^{*} / * * \&$ & $431.9 \pm 39.1^{*}$ \\
\hline Anakinra, $8 \mathrm{mg} / \mathrm{kg}$ & $15.61 \pm 0.97$ & $12.78 \pm 0.59 \&$ & $11.65 \pm 0.73^{*} \# \&$ & $8.88 \pm 0.74 * \# \&$ & $367.3 \pm 26.4^{*} / * *$ \\
\hline
\end{tabular}

Note. Statistically significant differences $(p \leq 0.05):{ }^{*}$ - to the intact control group; ${ }^{* *}$ - to the control pathology group;

\# - to metformin; \& - to the initial level; $\mathrm{n}$ - the number of animals in the group.

is a model of the absolute insulin deficiency of direct $\beta$-cytotoxic genesis $[4,12]$.

H. Okamoto has formulated the "zinc theory", according to which zinc interacts with a diabetogenic factor - dithizone to form toxic complexes leading to irreversible destructive changes in pancreatic $\beta$-cells $[4,10]$.

The model pathology was caused by a single intravenous injection of dithizone solution in the dose of $35 \mathrm{mg} / \mathrm{kg}$ given to male rabbits of Chinchilla breed with the weight of 2.8-3.4 kg previously fasted for 16-18 hours [4]. As reference drugs metformin (diaformin of "Farmak" JSC, tablets, $0.5 \mathrm{~g}$ ) and anakinra (Kineret produced by "Swedish Orphan Biovitrum" (Sweden), powder for injections, $100 \mathrm{mg}$ ) were selected.

The choice of reference drugs is conditioned by the fact that metofmin is the reference hypoglycemic drug included to the standard therapy of both types of diabetes, as well as it directly inhibits formation of products of nonenzymatic glycosylation $[6,10,13]$, and anakinra is a recombinant receptor antagonist IL-1 with the proven hypoglycemic activity, which is a complete analogue of the drug under research [15].

These drugs were administered in the therapeutic regimen: raleukin in the dose of $7 \mathrm{mg} / \mathrm{kg}$ and anakinra in the dose of $8 \mathrm{mg} / \mathrm{kg}$ subcutaneously [16], metformin in the dose of $30 \mathrm{mg} / \mathrm{kg}$ - intragastrically [9] once within 30 days from the next day after introduction of dithizone.

Intravenous glucose tolerance test (IGTT) was reproduced in rabbits by introduction of intravenous glucose solution in the dose of $500 \mathrm{mg} / \mathrm{kg}$ on the 30 -th day of the study. Blood samples for glucose analysis were taken before and after 5, 10, 30 and 60 min of glucose load [4, 9].

Hypoglycemic properties of drugs were assessed by the following parameters: basal glycemia in dynamics on the 10-th, 20 -th and 30-th day of the study, on the 30-th day the area under the glycemic curve (AGC), the coefficient of $\beta$-cell function (CBF), the dynamics of glycemia during IGTT [4].

The intensity of the initial reactions of nonenzymatic glycosylation was detemined by the values of glycosylated hemoglobin (HbA1c) and fructosamine levels in the blood serum of rabbits on the 30-th day of the research $[2,4]$.

Blood glucose was evaluated by the glucose oxidase test using the glucose enzymatic analyzer "Eksan-D" (Lithuania); AGC was calculated by "Mathlab" computer program [6].

Sensitivity of peripheral tissues to the action of insulin was determined by the HOMA method (Homeostatic Model Assessment) - a mathematical model of insulinglucose relationship by the formula 1 [5].

$$
\mathrm{CBF}=\frac{20 \times \text { fasting insulin }}{\text { fasting glucose }-3.5}
$$

The concentration of insulin is measured in microns $\mathrm{U} / \mathrm{ml}$, and the concentration of glucose is in $\mathrm{mmol} / \mathrm{l}$.

The level of HbA1c was determined by the colorimetric method using the reaction with thiobarbituric acid, the fructosamine content - by the method of Johnson R.N. [5].

When recording the results as mean \pm standard error the statistical reliability of intergroup differences was calculated by the Student t-test.

\section{Results and Discussion}

The results are shown in Tables 1-4.

Dithizone is 8-hydroxybenzopyridine, which is capable of forming chelate complexes with zinc and can induce insulin-dependent diabetes. Most studies indicate that zinc is actively involved in the synthesis, deposition and secretion of insulin and it is mainly located in the secretory granules of $\beta$-cells. It is believed that zinc ions contribute to the transformation of proinsulin into insulin and hormone excretion as a stable crystalline form of zincinsulin [4]. 
The effect of raleukin on glycemic dynamics in the conditions of the intravenous glucose tolerance test in rabbits with dithizonic diabetes $(n=5)$

\begin{tabular}{|c|c|c|c|c|c|}
\hline \multirow{2}{*}{ Group of animals } & \multirow{2}{*}{$\begin{array}{c}\text { Basal glycemia, } \\
\mathrm{mmol} / \mathrm{l}\end{array}$} & \multicolumn{4}{|c|}{ Glycemia in ... $\mathrm{min}, \mathrm{mmol} / \mathrm{l}$} \\
\hline & & 5 & 10 & 30 & 60 \\
\hline Intact control & $3.86 \pm 0.21$ & $5.23 \pm 0.17$ & $6.69 \pm 0.32$ & $4.48 \pm 0.29$ & $4.15 \pm 0.37$ \\
\hline Control pathology & $18.45 \pm 0.92^{*}$ & $\begin{array}{l}25.32 \pm \\
0.88^{*} \&\end{array}$ & $\begin{array}{l}29.94 \pm \\
1.56 * \&\end{array}$ & $\begin{array}{l}27.61 \pm \\
1.72 * \&\end{array}$ & $\begin{array}{l}23.37 \pm \\
0.78^{*} \&\end{array}$ \\
\hline Raleukin, $7 \mathrm{mg} / \mathrm{kg}$ & $9.27 \pm 0.63^{*} / * *$ & 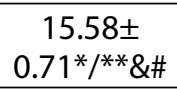 & $\begin{array}{c}18.36 \pm \\
1.08^{*} / * * \& \#\end{array}$ & $\begin{array}{c}13.49 \pm \\
0.92 *{ }^{* * *} \&\end{array}$ & $\begin{array}{c}11.61 \pm \\
0.66^{* / * * \#}\end{array}$ \\
\hline Metformin, $30 \mathrm{mg} / \mathrm{kg}$ & $12.13 \pm 0.84^{*} / * *$ & $\begin{array}{l}22.63 \pm \\
1.45^{*} \&\end{array}$ & $\begin{array}{c}25.82 \pm \\
\left.0.96 *\right|^{* * *} \&\end{array}$ & $\begin{array}{c}17.81 \pm \\
1.94 * / * * \&\end{array}$ & $\begin{array}{c}15.56 \pm \\
0.79 * / * * 8\end{array}$ \\
\hline Anakinra, $8 \mathrm{mg} / \mathrm{kg}$ & $9.12 \pm 0.76^{*} / * *$ & $\begin{array}{c}16.41 \pm \\
0.82^{*} / * * * \#\end{array}$ & 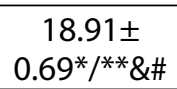 & $\begin{array}{c}13.04 \pm \\
0.47^{*} /^{* *} \& \#\end{array}$ & $\begin{array}{c}11.22 \pm \\
0.93^{*} /^{* *} \#\end{array}$ \\
\hline
\end{tabular}

Note. Statistically significant differences $(p \leq 0.05):{ }^{*}$ - to the intact control group; ${ }^{* *}$ - to the control pathology group; $\#$ - to metformin; \& - to the initial level; $\mathrm{n}$ - the number of animals in the group.

Therefore, on the second day after injection of dithizone in experimental animals there was a sharp increase in basal hyperglycemia (on the average by 4.6 times), which remained there to the end of the study (on the average 3.8 times higher than the value in the group of intact animals) (Table 1). This indicates the absence of spontaneous remission and relevance of the chosen model for testing anti-diabetic properties of raleukin.

Basal glycemia in all groups of the experimental animals with diabetes at baseline (the second day after administration of dithizone) was equal to about $16-17 \mathrm{mg} / \mathrm{dL}$ and was also accompanied by a double decrease in the concentration of insulin in the blood serum. In this case only an absolute deficiency of insulin without the inclusion of autoimmune components corresponding to type 1 diabetes in humans was reproduced $[2,4]$.
The increased area under the glycemic curves (AGC) on the 30-th day of the research (Table 1) testified the marked insulin deficiency in rabbits of the control pathology group.

It has been found that the use of all drugs under research within a month contributes to a significant reduction of basal hyperglycemia and AGC value though the values of animals from the intact control group are not reached (Table 1).

By the normalized effect on basal glycemia on the 20-th and 30 -th days of the study raleukin (1.2 times) and anakinra (1.2 times on the 20-th and 1.3 times on the 30-th day) exceeded metformin. Raleukin and anakinra also significantly reduced AGC by 1.3 and 1.4 times, respectively, compared to the similar value of the control pathology group. Metformin showed only a tendency to AGC decrease. There was no sig- nificant difference between the hypoglycemic action of raleukin and anakinra.

Introduction of drugs studied within thirty days contributed also to the possible reduction of glucose tolerance, and it was proven in the conditions of IGTT. Under the influence of raleukin and anakinra in 60 minutes glycemia was not significantly different from the basal one in the corresponding group, and on the background of metformin it was 1.3 times higher than the basal one (Table 2).

In the conditions of IGTT a distinct insulin deficiency was observed in animals of the control pathology group as evidenced by 5.2 times increase in the AGC value and 112.5 times decrease of the CBF value compared to those of the intact control group (Table 3 ).

A significant increase of CBF (3.2 times under the action of raleukin, 3.4 times under the influ-

Table 3

The effect of raleukin on the values of glucose homeostasis in the conditions of the intravenous glucose tolerance test in rabbits with dithizonic diabetes on the 30 -th day $(n=5)$

\begin{tabular}{|l|c|c|c|c|c|}
\hline \multicolumn{1}{|c|}{ Value } & $\begin{array}{c}\text { Intact } \\
\text { control }\end{array}$ & $\begin{array}{c}\text { Control } \\
\text { pathology }\end{array}$ & $\begin{array}{c}\text { Raleukin, } \\
7 \mathrm{mg} / \mathrm{kg}\end{array}$ & $\begin{array}{c}\text { Metformin, } \\
30 \mathrm{mg} / \mathrm{kg}\end{array}$ & $\begin{array}{c}\text { Anakinra, } \\
8 \mathrm{mg} / \mathrm{kg}\end{array}$ \\
\hline Basal glycemia, $\mathrm{mmol} / \mathrm{L}$ & $4.15 \pm 0.37$ & $23.37 \pm 0.78^{*} \&$ & $11.61 \pm 0.66^{*} / /^{* *}$ & $15.56 \pm 0.79^{*} /{ }^{* *} \&$ & $11.22 \pm 0.93^{*} /{ }^{* * \#}$ \\
\hline $\mathrm{AGC}, \mathrm{mmol} / / \mathrm{min}$ & $240.3 \pm 17.5$ & $1254.6 \pm 89.4^{*}$ & $626.4 \pm 57.1^{* / * * \#}$ & $830.7 \pm 63.6^{*} /{ }^{* *}$ & $610.2 \pm 47.2^{* * * * \#}$ \\
\hline $\mathrm{CBF}$ & $2767.5 \pm 228.1$ & $24.6 \pm 1.8^{*}$ & $78.7 \pm 6.4^{*} / /^{* *} \#$ & $54.3 \pm 5.7^{*} /{ }^{* *}$ & $82.6 \pm 6.9^{* / * * \#}$ \\
\hline
\end{tabular}

Note. Statistically significant differences $(p \leq 0.05):{ }^{*}$ - to the intact control group; ${ }^{* *}$ - to the control pathology group; \#- to metformin; $\mathrm{n}$ - the number of animals in the group. 
Table 4

The effect of raleukin on the concentration of initial products of nonenzymatic glycosylation in rabbits with dithizonic diabetes on the 30 -th day $(n=5)$

\begin{tabular}{|l|c|c|c|c|c|}
\hline \multicolumn{1}{|c|}{ Value } & $\begin{array}{c}\text { Intact } \\
\text { control }\end{array}$ & $\begin{array}{c}\text { Control } \\
\text { pathology }\end{array}$ & $\begin{array}{c}\text { Raleukin, } \\
7 \mathrm{mg} / \mathrm{kg}\end{array}$ & $\begin{array}{c}\text { Metformin, } \\
30 \mathrm{mg} / \mathrm{kg}\end{array}$ & $\begin{array}{c}\text { Anakinra, } \\
8 \mathrm{mg} / \mathrm{kg}\end{array}$ \\
\hline $\mathrm{HbA} 1_{c^{\prime}} \%$ & $2.26 \pm 0.19$ & $6.41 \pm 0.52^{*}$ & $3.07 \pm 0.34^{* * \#}$ & $4.14 \pm 0.28^{*} /{ }^{* *}$ & $2.75 \pm 0.21^{* * \#}$ \\
\hline Fructosamine, $\mathrm{mmol} / \mathrm{L}$ & $0.81 \pm 0.10$ & $2.77 \pm 0.56^{*}$ & $1.74 \pm 0.26^{* *}$ & $1.57 \pm 0.32 \pm$ & $1.39 \pm 0.14^{* *}$ \\
\hline
\end{tabular}

Note. Statistically significant differences $(p \leq 0.05)$ : * to the intact control group; ${ }^{* *}$ - to the control pathology group; $\#$ - to metformin; $\mathrm{n}$ - the number of animals in the group.

ence of anakinra, 2.2 times on the background of metformin) and decrease of AGC $(2$ times on the background of raleukin and anakinra and 1.5 times under the action of metformin) were also the confirmation of insulin deficiency reduction in animals with the model diabetes who received the drugs under research. It indicates decrease of the hyperglycemic response to glucose load (Table 3 ). By the normalized effect on the values of $\mathrm{CBF}$ and $\mathrm{AGC}$ raleukin and anakinra significantly exceeded metformin.

Determination of HbA1c in the blood serum of rabbits in the control pathology group revealed its significant increase by 2.8 times compared to the intact control group confirming the presence of persistent hyperglycemia within thirty days (Table 4).

Application of raleukin, anakinra and metformin led to a significant reduction in the abovementioned value. It confirms the data about improvement of the glycemic control. So, on the background of raleukin and anakinra the content of HbA1c was not significantly different from the value of the intact control group, under the influence of metformin it significantly differed from the values of the intact control group and groups of raleukin and anakinra.

The level of fructosamine in the blood serum in rabbits of the control pathology group on the 30-th day of the research significantly increased by three times compared to the value of the intact control group (Table 4). Introduction of both receptor antagonists IL-1 and metformin promoted a significant decrease in the fructosamine concentration (1.6 times on the background of raleukin, twice on the background of anakinra, 1.8 times under the influence of metformin). It also confirms the positive impact of these drugs on glucose homeostasis.

Thus, our study has shown the presence of hypoglycemic properties in raleukin on the model of dithizonic diabetes in rabbits. By the intensity of the hypoglycemic effect raleukin is not significant- ly inferior to the reference drug anakinra and exceeds metformin.

It can be assumed that the hypoglycemic effect of raleukin develops not only because of blocking IL-1 receptors in the pancreas and further protection of $\beta$-cells from the cytotoxic effects of dithizone, but also due to inhibition of formation of nonenzymatic glycosylation products. The ability of raleukin to inhibit the synthesis of Amadori products (HbA1c, fructosamine) can be one of the mechanisms of its angioprotective properties under the conditions of diabetes.

\section{CONCLUSIONS}

It has been found that on the model of dithizonic diabetes in rabbits recombinant receptor antagonist IL-1 raleukin has a strong hypoglycemic effect, which intensity is not inferior to anakinra and exceeds metformin.

The results of the studies conducted indicate perspectiveness of further research of antidiabetic properties of raleukin in order to include the drug to the complex treatment of type I diabetes.

\section{REFERENCES}

1. Балаболкин М.И., Клебанова Е.М., Креминская В.М. Лечение сахарного диабета и его осложнений. M., 2005. - 512 c.

2. Горбенко Н.I., Полторак В.В., Гладких О.І., Іванова О.В. // Вісник фармації. - 2000. - №1 (21). C. 44-46.

3. Дедов И.И. // Вестник Росс. академии мед. наук. - 2012. - №1. - С. 7-13.

4. Доклінічні дослідження лікарських засобів: Метод. рекоменд. / За ред. чл.-кор. НАМН України О.В.Стефанова. - К.: Авіценна, 2001. - 528 с.

5. Камышников В.С. Справочник по клиническо-биохимической лабораторной диагностике: в 2-х т. Мн: Беларусь, 2002. - T. 1. - 495 с.; T. 2. - 463 c.

6. Полторак B.B. // Medicus Amicus. - 2005. - №5. - C. 16.

7. Сунцов Ю.И., Болотская Л.Л., Маслова О.В. и др. // Сахарный диабет. - 2011. - №1. - С. 15-18. 
8. Тронько М.Д., Чернобровий А.Д. Поширеність цукрового діабету в областях України за 2008 рік / В кн.: Основні показники діяльності ендокринологічної служби України за 2008 рік. - К.: АМНУ, МОЗУ, 2009. - С. 18.

9. Шумейко О.Г. Експериментальне обгрунтування застосування екстракту з мідії чорноморської (Mytilus galloprovincialis Lam.) у комплексній терапії цукрового діабету : Дис. ... канд. мед. наук: 14.01.14 - ендокринологія. - Х., 2009. - 153 с.

10. Beisswenger P., Ruggiero-Lopez D. // Diabetes Metabol. - 2003. - Vol. 29. №4. - P. 6S95-6S103.

11. Börjesson A., Carlsson C. // J. Endocrinol. - 2007. - Vol. 192 (2). - P. 381-387.

12. Cnop M., Welsh N., Jonas J.C. et al. // Diabetes. - 2005. - Vol. 54, Suppl. 2. - P. S97-S107.

13. Guigas B., Deaille D., Chauvin C. et al. // Biochem J. - 2004. - Vol. 382, №3. - P. 877-884.

14. Lagathu C., Yvan-Charvet L., Bastard J.P. et al. // Diabetol. - 2006. - №49. - P. 2162-2173.

15. Mandrup-Poulsen T., Bendtzen K., Dinarello C.A. et al. //J. Immunol. - 1987. - Vol. 139 (12). - P. 4077-4082.

16. Sandgerg J.O., Andersson A., Eizirik D.L. et al. // Biochem. Biophys. Res. Commun. - 1994. - Vol. 202 (1). P. 543-548.

\title{
ЕКСПЕРИМЕНТАЛЬНЕ ВИВЧЕННЯ ВПЛИВУ РАЛЕЙКІНУ НА ПЕРЕБІГ ДИТИЗОНОВОГО ДІАБЕТУ В КРОЛІВ
}

І.П.Бухтіярова, С.М.Дроговоз , Є.М.Коваленко

Донецький національний медичний університет ім. М.Горького, Національний фармацевтичний університет*

Ключові слова: дитизоновий діабет; продукти неферментативного глікозилювання; гіпоглікемічна дія; ралейкін

\begin{abstract}
У структурі ендокринних захворювань цукровий діабет (ЦД) посідає друге місце після патології щитоподібної залози. У 2012 р. в Україні зареєстровано понад 1 млн хворих на ЦД, тому оптимізація терапї цієї хвороби $\epsilon$ однією з актуальних медичних та соціальних проблем сучасності. В основі патогенезу найбільш серйозних ускладнень ЦД (тромбозів, атеросклерозу, ниркової недостатності, катаракти тощо) лежать процеси неферментативного глікозилювання. Враховуючи наявність у рекомбінантного антагоніста рецепторів ІЛ-1 ралейкіну антиоксидантних властивостей та визначеної у попередніх дослідженнях гіпоглікемічної дії, ми вивчили його вплив на початкові реакції неферментативного глікозилювання. Наведені результати вивчення впливу рекомбінантного антагоніста рецепторів ІЛ-1 ралейкіну, отриманого у Санкт-Петербурзькому НДІ ОЧБП, на перебіг дитизонового діабету у кролів. Визначено, що на моделі дитизонового діабету у кролів рекомбінантний антагоніст рецепторів ІЛ-1 ралейкін чинить виражену гіпоглікемічну дію, за вираженістю якої не поступається референт-препарату анакінра та переважає метформін. Результати проведених досліджень свідчать про перспективність подальшого вивчення антидіабетичних властивостей ралейкіну з метою включення даного препарату до комплексної терапї̈ ЦД I типу.
\end{abstract}

\section{ЭКСПЕРИМЕНТАЛЬНОЕ ИЗУЧЕНИЕ ВЛИЯНИЯ РАЛЕЙКИНА НА ПРОТЕКАНИЕ ДИТИЗОНОВОГО ДИАБЕТА У КРОЛЕЙ}

И.П.Бухтиярова, С.М.Дроговоз*, Е.Н.Коваленко

Донецкий национальный медицинский университет им. М.Горького, Национальный фармацевтический университет*

Ключевые слова: дитизоновый диабет; продукты неферментативного гликозилирования; гипогликемическое действие; ралейкин

В структуре эндокринных заболеваний сахарный диабет (СД) занимает второе место после патологии щитовидной железы. В 2012 г. в Украине зарегистрировано более 1 млн больных СД, поэтому оптимизация терапии этого заболевания является одной из актуальных медицинских и социальных проблем современности. В основе патогенеза наиболее серьезных осложнений СД (тромбозы, атеросклероз, почечная недостаточность, катаракта и др.) лежат процессы неферментативного гликозилирования. Учитывая наличие у рекомбинантного антагониста рецепторов ИЛ-1 ралейкина антиоксидантных свойств и доказанного в предыдущих исследованиях гипогликемического действия, мы изучили его влияние на начальные реакции неферментативного гликозилирования. Приведены результаты изучения влияния рекомбинантного антагониста рецепторов ИЛ-1 ралейкина, полученного в Санкт-Петербургском НИИ ОЧБП, на протекание дитизонового диабета у кролей. Определено, что на модели дитизонового диабета у кролей рекомбинантный антагонист рецепторов ИЛ-1 ралейкин оказывает выраженное гипогликемическое действие, по выраженности которого он не уступает референс-препарату анакинра и превосходит метформин. Результаты проведенных исследований свидетельствуют о перспективности дальнейшего изучения антидиабетических свойств ралейкина с целью включения данного препарата в комплексную терапию СД I типа. 